A. Klymchuk, Cand. Sc. (Econ.), orcid.org/0000-0002-5246-8778
Vinnytsia National Agrarian University, Vinnytsya, Ukraine, e-mail: alena_klumchyk@ukr.net

\title{
THE LABOR ASSESSMENT IN FORMING THE ENTERPRISE PERSONNEL'S MOTIVATION
}

Purpose. Development of specific methodological approaches to the assessment of the employees' activity at enterprises in the formation of their motivation based on the modern theoretical and methodological achievements of effective HR management.

Methodology. The research is carried out on the basis of use of fundamental and modern provisions of economic theory, management, and data of scientific schools of motivation theories of foreign and domestic scientists-economists, experts in the field of HR management. With the help of systematic analysis and synthesis the essence of staff's activity assessment has been investigated and its significance in the management process has been defined. The method of comparison is used to study methodological approaches to staff performance assessment at the foreign and domestic enterprises and organizations, the graphical method - for the schematic representation of the motivation influence on the staff performance assessment. Types of staff assessment were classified with their differentiation for managers at various levels, experts, professionals, technical staff and workers, which will determine the criteria for the staff performance assessment, depending on the assigned tasks to enhance the labour activity motivation.

The method for constructing the indicator, which includes quantitative assessment of staff performance based on the points, has been used.

Findings. The significance and value of the methodological approach to the staff performance assessment for various professional and qualification groups has been proved, the traditional and innovative methods of assessment at enterprises have been analysed. In order to solve the existing problems as for the selection of appropriate techniques for the staff performance assessment at domestic enterprises, we have developed reference classification of types of staff work assessment with the selection of specific types for workers of various skill levels and have suggested using a comprehensive staff performance assessment based on the points quantitative expression. It has been concluded that the effectiveness of achieving good results in the staff performance assessment is determined by two important components: the external component (the drives that shape the enterprise activity effectiveness) and the internal component (motives that shape to meet the employee's needs).

Originality. The development of a methodological approach to the staff performance assessment, which is the core of staff work motivation and provides the relevant achievements of goals, allows revealing the weak points in the enterprise activity and to interest the workers themselves in correcting the current situation. As a result of proper staff activity assessment, it is possible to obtain information on the effectiveness of the employees' work; potential opportunities of professionals and their career prospects; the causes of inefficient work of certain employees; the needs and priorities in education and staff development; selection of effective tools at their work promotion.

Practical value. The use of comprehensive methods of staff performance assessment enables to carry out comprehensive assessment effectively of both an individual employee of various professional and functional grades and a staff group in general that allows offering measures for their motivation and encouragement in the future. The proposed types of assessment allow choosing the types and methods of assessment for managers at various levels, experts, specialists and employees of structural divisions, determining staff assessment criteria, depending on the assigned tasks to enhance its motivation and encouragement.

Keywords: staff performance assessment, comprehensive assessment

Introduction. In modern conditions of national economy development the human factor plays a decisive role in the successful functioning of any business entity. That is why the use of appropriate methods of staff assessment at all stages (staff recruitment, adaptation, training and development, daily performance, even dismissal) makes it possible to determine the economic interest of managers at enterprises in productive and qualitative work of their subordinates, and to create effective mechanisms to promote and enhance their motivation to work. Despite the fact that domestic enterprises successfully use foreign methods of staff assessment, for today standard approaches are not fully processed as for

(C) Klymchuk A., 2018 selection and use of these methods, depending on the economic activities of enterprises and their industry focus, which requires more in-depth research in this direction.

Analysis of recent research and publications. The problems of methodological support of the process of staff performance assessment have been researched by such well-known foreign scholars as Paul Iles, Gerald Randall, Crist Rast, Gary Dessler, and Douglas Bray, whose works have paid much attention to the theoretical approaches to the staff assessment. However, domestic and Russian scientists focus much attention on borrowing of foreign experience in shaping of new approaches to the staff performance assessment as well as of the specific features of their practical application. 
In particular, according to O. G. Gavrilova, staff performance assessment is a management component and a complex system of staff rating used at the enterprise or organization [1]. We believe that this concept is much broader and more meaningful, is not defined as a rating, which is only the structural component among others, but is a constituent of enterprise management system.

It is quite appropriate to carry out the differentiation of staff assessment methods into traditional and alternative. The first methods focus on an individual employee and are based on a manager's or colleagues' subjective value. However, their disadvantage is that the assessment given to an individual employee without taking into account company goals, is based on the head's assessment with complete disregard of opinions of colleagues, subordinates, customers; they focus on the results achieved and do not include long-term development prospects of the enterprise and the employee. The alternative methods of staff performance assessment are directed to the working group (subdivision, brigade, collective) consideration and focus on an employee assessment by their colleagues and the ability to work in a group; the assessment of an individual employee and the working group is carried out and based on the results of the entire enterprise, taking into account not only the successful execution of the current duties, but also the capacity for professional development and new skills and knowledge development. As for objective, target and operational assessments, the existing methods are combined into three groups: qualitative, quantitative and combined.

In the opinion of the group of the authors [2], from the theoretical and practical points of view, it is important to distinguish between two types of staff performance assessment: self-assessment (the system of representations, standards, images: perfect image of "Self"; normative image of "Self", namely, an idea of what a person should be to be perceived and respected by others) and external assessment (an objective assessment of oneself on the part of the collective, managers, direct consumers of the products of labour). However, the researchers affirm that the absence of one type of the assessment may contribute to the development of even negative phenomena.

According to the authors [3], by the form of final result expression the descriptive (the assessment is submitted in the text form), quantitative and combined methods (the ratio scales are used that allow quantifying different levels of performance at the enterprise) are distinguished. By the assessment tools the prognostic assessment methods, whose information base is the result of surveys, interviews, strategy sessions; practical methods, based on the assessment of the results of an employee's practical activity; simulation methods involve the employee's assessment by their behaviour in a particular situation are distinguished.

According to the experience of foreign countries, there are different methods and techniques of employees' performance assessment. In particular, at enterprises in Japan they are based on the specific features of the Japanese philosophy with the characteristics defined for each employee, their skills, character and capabilities to the certain work. Along with this, in the USA, by the results of the performed research of the employees of General Electric Corporation, criticism that is a means of informing subordinates on the deficiencies in their work is defined as a discouraging factor. With that, bilateral constructive discussion aimed at solving specific issues of performance improvement is an effective driver. In company Control Data an important constituent is self-esteem, which creates favourable conditions for an employee to consider their strong and weak points with the aim of further discussion and making appropriate adjustments.

Along with this, Business Personality Test (BPT), which includes about 100 questions, takes a significant place for employees' assessment in the countries of Western Europe. Test results are assessed by a flexible scale ( 0 to 10 points), which makes it possible with the help of the answers to each question posed to get the detailed information that is far more effective than traditional methods for answers' assessment via the "yes/ no" system or selecting a pre-embedded response. Famous Ukrainian commercial bank "PrivatBank" uses the staff assessment testing Midot (Midot System is an innovative solution for assessment of risks of staff destructive behaviour or abuses).

As an effective method for employees' work assessment at enterprises, S. O. Tsymbaliuk [4] suggests using the grading system that is an effective encouraging mechanism designed to form a differentiated system of staff remuneration for labour contributions and it is based on the assessment of job complexity for various positions.

Ivanova M.I. and Yehorov N.O. [5] hold to this opinion, where as exemplified by industrial enterprises they recommend to introduce a system of grades. Due to this system the head of an enterprise has an opportunity to encourage professionals by not paying inducements in cash to those who have not deserved it yet. Mukha R. [6] considers that an effective method of staff activity assessment at industrial enterprises is the use of the method "360 degrees", which allows fully appreciating both personal and professional competences of an employee. According to this method an employee is assessed using a wide range of experts - a head and colleagues. The employee, who is assessed, should be involved in the assessment, and he/she makes self-assessment. Typically, the use of this method is most effective for determining the employees' needs in training, their skill level on a number of criteria, at the formation of personnel reserve, the relocation of employees within the enterprise, which, in its turn, helps determine ways to improve productivity at the enterprise. The main point is that this method is used to determine the encouragement tools at the enterprise, which enables to get more complete and objective information about factors that influence the staff motivation.

In addition, there are a number of psycho-diagnostic methods that should be used in assessing the staff performance [7]. However, their analysis makes it possible to assert that they are aimed at determining only em- 
ployees' psychological constituent and relationships in the collective.

Unsolved aspects of the problem. Choosing an effective methodological approach to the staff performance assessment is the most important part of it; unfortunately, there is no common classification of existing methodological approaches to the assessment of labour activity of employees at an industrial enterprise nowadays. This is because the existing methods and techniques of staff performance assessment are characterized by their diversity and ambiguity, which creates imperfection in the elaboration of standard approaches to the selection and use of these techniques, depending on the types of economic activities of enterprises and their industrial focus, which requires more in-depth research studies in this direction. According to our beliefs, we should use the methodological approaches that are aimed at determining the effectiveness and efficiency of management decisions taken as for the staff. In addition, after the staff activity assessment it is necessary to develop certain constructive recommendations, which, depending on the situation, require carrying out certain organizational and personnel procedures.

Objectives of the article. The objective of our research is the process of selection of specific methodological approaches to the assessment of the employees' activity at industrial enterprises in the formation of their motivation based on the modern theoretical and methodological achievements of effective HR management.

Presentation of the main research. The staff performance assessment is necessary to be understood as a process of comparing an employee's skills with the defined benchmark, whereby it can determine adequacy (inadequacy) for the job and an employee's ability (inability) to solve the assigned tasks. The benchmark may be either the most dedicated employee's work, or the sum of the best results of separate components of work of different people.

Along with this, the integral part of the selection process of methods of staff performance assessment is classification of its assessment types (Table), where we have offered the following types of assessment: by content - comprehensive assessment; by the regularity of carrying out - occasional; by a period of carrying out perspective; by the implementation criteria - analytical; by the system of carrying out - systemic; by the subject of carrying out - external; according to the classification of the staff - by the functional structure (senior, middle and down managers, officials, blue collars, experts, specialists, direct and auxiliary personnel, workers of manual and mechanical work) and by skill level (specialists of top, high and average qualification, subprofessionals, highly qualified, qualified, low-skilled, unskilled workers).

Senior management performance assessment should be carried out by the following categories: by content comprehensive assessment; by regularity - periodic and occasional; by the period - final and perspective; by assessment criteria - analytical. To assess the senior management performance we offer a comprehensive assessment of their activities, since its regular use is impracti- cal, as the senior management performance is the result of the enterprise functioning as a whole, the effectiveness assessment of which can be determined only on the fixed date or period. Because of this for the assessment of manager's ability to achieve the stated goal, their ability to control and manage both the staff and the enterprise activities in general, it is advisable to use periodic and episodic assessment. Thus, periodic assessment allows evaluating the senior management performance only for a certain period, while occasional assessment their work. Final and perspective assessment should be carried out according to the period of assessment. According to the set criteria we suggest using an analytical assessment that allows us to generalize all types of assessment and managers' performance. At senior management performance assessment it is necessary to apply the exterior view of the assessment, namely the assessment by the subjects of external interactions, by a special commission and experts that will determine its competitive advantages most objectively.

Middle management performance assessment is important from the point of view of determination of performance through the implementation of the assigned tasks by a structural subdivision or department over a particular period of time. Middle management performance assessment should be based on such types of assessment: by content - comprehensive; by regularity periodic and occasional; by the period - final and perspective; by assessment criteria - qualitative, temporal guidelines assessment and analytical.

The difference between the types of assessment of senior and middle management lies only in assessment criteria. In accordance with the assessment criteria, it is suggested using qualitative assessment, assessment by temporal guidelines and analytical assessment. The suggested types of assessment allow providing efficiency and rationality of the process of middle management performance assessment.

At lower-level management performance assessment it is very important to apply the following types of assessment: by content - comprehensive; by regularity regular, periodic; by the period - current, final and perspective; by assessment criteria - quantitative, qualitative and analytical; by consistency - systemic. The difference in the assessment of lower-level managers and other types of managers' performance lies in their duties. Thus, if the duties of senior and middle management involve mostly solving organizational and managerial tasks, then the lower-level management is responsible for the implementation of target tasks of the department or workshop, i.e. a clear labour outcome. Thus, according to the regularity of carrying out evaluation, it is recommended to use regular and periodic assessment. Along with this it is advisable to carry out lower-level management permanent monitoring and performance assessment as well as generalized periodic assessment aiming at assessing performance over a certain period of time. Thus, according to the assessment period, it is suggested performing the current, final and perspective assessment that allows assessing the results of each day and over a certain period of time, and in 
Characteristics of staff performance assessment types

\begin{tabular}{|c|c|c|}
\hline $\begin{array}{l}\text { Classification } \\
\text { feature }\end{array}$ & Assessment type & Characteristics of the assessment type \\
\hline \multirow[t]{2}{*}{ By content } & Partial & Only a performer's certain qualities or performance is assessed \\
\hline & Comprehensive & $\begin{array}{l}\text { Integrated characteristics of business and personal qualities, labour behaviour, } \\
\text { performance are assessed }\end{array}$ \\
\hline \multirow[t]{3}{*}{ By regularity } & Regular & Carried out on a regular basis \\
\hline & Periodic & Carried out every six months, year, and several years \\
\hline & Occasional & $\begin{array}{l}\text { Conditioned by a specific event (completion of probation term, promotion, } \\
\text { disciplinary liability measures) }\end{array}$ \\
\hline \multirow[t]{3}{*}{$\begin{array}{l}\text { By the time } \\
\text { period }\end{array}$} & Perspective & $\begin{array}{l}\text { Defines abilities, qualities, motivation, expectations about future challenges } \\
\text { and enables to forecast potential opportunities }\end{array}$ \\
\hline & Final & Assesses the performance and its results after a certain time period ( $1-5$ years) \\
\hline & Current & Determines the level of current duties performance by an employee \\
\hline \multirow[t]{4}{*}{ By the criteria } & Quantitative & Assessment of a number of assignments and responsibilities performed \\
\hline & Qualitative & Assessment of quality of assignments and responsibilities performed \\
\hline & Analytical & Consolidated report of all assessments by all criteria \\
\hline & Of temporal guidelines & $\begin{array}{l}\text { Assessment of the quality and number of assignments and responsibilities } \\
\text { performed over a certain period of time }\end{array}$ \\
\hline \multirow[t]{2}{*}{ By consistency } & Systemic & Assessment by all units of the system \\
\hline & Random & $\begin{array}{l}\text { The right of choice of criteria, methods, techniques, tools and assessment } \\
\text { procedures }\end{array}$ \\
\hline \multirow[t]{7}{*}{ By the subject } & Self-assessment & $\begin{array}{l}\text { The employees' internal assessment of themselves, their labour efforts to give } \\
\text { suggestions as for enhancement of their productivity by the employees }\end{array}$ \\
\hline & $\begin{array}{l}\text { External: } \\
\text { assessment, carried out } \\
\text { directly by the manager }\end{array}$ & $\begin{array}{l}\text { Assessment of an employee by his/her manager, subordinates, colleagues, } \\
\text { customers, i.e. comprehensive assessment }\left(360^{\circ}\right) \text {. } \\
\text { Is of the greatest value as it includes the staff assessment by the most competent } \\
\text { and qualified personnel. The greatest value makes up the assessment by the top } \\
\text { management, the colleagues' assessment is very important }\end{array}$ \\
\hline & assessment by the colleagues & $\begin{array}{l}\text { It is quite significant as the subject is a specially prepared group of professionals } \\
\text { and the object can be a manager or any employee of the enterprise }\end{array}$ \\
\hline & $\begin{array}{l}\text { assessment, carried out by } \\
\text { the subordinates }\end{array}$ & $\begin{array}{l}\text { It is less important as the efficiency of the manager performance assessment by } \\
\text { the subordinates depends on the level of the collective development: the lower } \\
\text { the level of its development is, the more distorted the assessment criteria are }\end{array}$ \\
\hline & $\begin{array}{l}\text { assessment, carried out by } \\
\text { the subjects of external } \\
\text { interaction (partners, } \\
\text { consumers) }\end{array}$ & $\begin{array}{l}\text { It is quite informative as it indicates the level of staff work satisfaction by the } \\
\text { key participants of the process }\end{array}$ \\
\hline & $\begin{array}{l}\text { assessment, carried out by a } \\
\text { special commission (e.g. } \\
\text { certifying commission) }\end{array}$ & $\begin{array}{l}\text { Comparison of specific characteristics of the employee's activities with theresults of } \\
\text { their work. In this case the use of observation methods, documentation } \\
\text { examination, working hours recording and others is effective }\end{array}$ \\
\hline & $\begin{array}{l}\text { assessment, carried out by } \\
\text { specially invited experts } \\
\text { (specialists from other } \\
\text { enterprises, consulting and } \\
\text { accounting firms, educational } \\
\text { institutions, and others) }\end{array}$ & $\begin{array}{l}\text { Assessment is carried out in accordance with pre-defined criteria. The employees } \\
\text { of three official levels can be assigned as experts: the level lower than that which is } \\
\text { assessed; with the same position; the higher level. The assessment can have both } \\
\text { qualitative and quantitative characteristics }\end{array}$ \\
\hline \multirow[t]{2}{*}{$\begin{array}{l}\text { By the object } \\
\text { of assessment }\end{array}$} & Individual assessment & $\begin{array}{l}\text { Provides the assessment of an individual employee performance. The } \\
\text { drawbacks of this assessment are: there is no purposefulness or the subject's } \\
\text { prejudgment, diffusion of evaluative statements }\end{array}$ \\
\hline & Group assessment & $\begin{array}{l}\text { Group diagnostics is conducted while studying mechanisms of formation, } \\
\text { functioning and development of team work, while studying other aspects of } \\
\text { group dynamics. It is necessary when it is impossible to assess a particular } \\
\text { individual worker by a specific indicator. In this case, the whole group } \\
\text { assessment is made and the employee's role in achieving this indicator is } \\
\text { defined by a number of indirect criteria }\end{array}$ \\
\hline
\end{tabular}


End of Table

\begin{tabular}{|c|c|c|}
\hline \multirow{3}{*}{$\begin{array}{l}\text { By the goals of } \\
\text { assessment: }\end{array}$} & $\begin{array}{l}\text { with the aim of } \\
\text { operating management of } \\
\text { employee's } \\
\text { performance }\end{array}$ & Current staff assessment is carried out \\
\hline & $\begin{array}{l}\text { with the aim of } \\
\text { establishing an } \\
\text { employee's job } \\
\text { adequacy }\end{array}$ & A staff certification is carried out \\
\hline & $\begin{array}{l}\text { with the aim of } \\
\text { identifying potential abilities } \\
\text { of a candidate for the vacant } \\
\text { position }\end{array}$ & Assessment of candidates for the vacant position is carried out \\
\hline $\begin{array}{l}\text { By the } \\
\text { professional } \\
\text { and functional } \\
\text { structure }\end{array}$ & $\begin{array}{l}\text { According to the staff } \\
\text { classification }\end{array}$ & $\begin{array}{l}\text { Assessment by the prescribed staff classification: by the functional structure } \\
\text { (senior, middle and low-level managers, officials, blue collars, experts, } \\
\text { specialists, direct and auxiliary personnel, workers of manual and mechanical } \\
\text { work) and by skill level (specialists of top, high and average qualification, } \\
\text { sub-professionals, highly qualified, qualified, low-skilled, unskilled workers) }\end{array}$ \\
\hline
\end{tabular}

prospect. According to the assessment criteria we suggest carrying out quantitative, qualitative and analytical assessment since under these circumstances there is a specific labour outcome. By the subject, according to our beliefs, it is appropriate to conduct the external assessment: assessment by the subjects of external interactions, by a special commission and experts.

Officials', experts' and specialists' performance assessment is appropriate to carry out by the following types: by content - comprehensive assessment; by regularity - permanent, periodic and occasional; depending on the period of assessment - current, final and perspective; by the set criteria - analytical assessment; by consistency - systematic assessment; by the subject external (assessment by the manager, the subjects of external interactions, by a special commission and experts). Performance assessment of the staff of the given professional-functional category provides the efficiency of solving both current and final duties and tasks by them as this category of employees includes accountants, specialists, experts and others.

As for the next staff professional and functional category, the employees' performance assessment is a very important process, because with the help of the results of their work, which is determined by the quality and quantity of manufactured products, the works performed and services rendered, the total performance of the company is provided.

The essence of the technique lies in the assessment of the interconnection of the agreed indicators of the constituents that make up a comprehensive staff assessment of

$$
R_{c e a}=0.5 * R_{p q} * B_{e}+C_{f} * P_{a},
$$

where $R_{\text {cea }}$ is an employee's comprehensive assessment; $R_{p q}$ is an employee's professional qualification level; $B_{e}$ stands for an employee's business characteristics; $C_{f}$ stands for the complexity of functions (work), they perform; $P_{a}$ is the performance assessment.

While assessing the employees' professional and qualification level, a set of components which includes education, relevant professional experience, and activity in proficiency enhancement is used. It is advisable to divide all employees into several groups according to their education (general secondary education, technical school, vocational school or college, higher education, and others), each of which is provided with appraisal by points. Depending on the length of relevant professional experience, each year is estimated by a certain number of points (up to 15 years -0.01 point a year, 15 years and more -0.15 points a year). Taking into account the form of training and staff development, an employee is also assessed by points. That is why the ratio of professional and qualification level (Rpq) is determined by the formula

$$
R_{p q}=\frac{(E d+E x p+A)}{0.85}
$$

where $E d+E x p+A$ is respectively a mark for education $(E d)$, relevant professional experience (Exp), activity in proficiency enhancement $(A) ; 0.5$ is the empirically determined coefficient, defined by the Research Institute of Labour, which enforces the value of complexity and job performance assessment; 0.85 is maximum appraisal by points of professional and qualification level.

Every characteristic of an employee's business features $(\mathrm{Be})$ is assessed in points, highlighting four levels of performance: low -0.5 ; average -1 ; above average 2 ; high -3 .

The characteristics that have an impact on the complexity of the employees' work and require more experience and applied efforts are the basis for assessing the complexity of an employee's functions (work) $\left(C_{f}\right)$. The mentioned coefficient is determined by the ratio of all assessments by each parameter, taking into account their proportion to the constant value 8.3 (the maximum appraisal by points by all parameters of the complexity of an employee's functions), provides the comparability in assessing the work complexity from an employee to a director. The performance assessment $\left(P_{a}\right)$ is determined by summing parameters of levels of assessments that determine the employees' performance, taking into account their proportion with the coverage of 
quantitative and qualitative parameters of the work performed.

It should be noted that each of the constituents of the formula refers to the composite values, which is composed with the help of specific features. Because of that we believe that the use of the indicated approach at the comprehensive staff assessment is fully grounded and well-targeted.

Along with this, the achievement of high performance of the employees' work is possible only with the emergence of needs and interests, which, in its turn, encourages an employee to activate his/her labour activity, which contributes to high labour motivation. Thus, the effectiveness of the staff performance just depends on the motives and incentives.

That is, in order to get good results at the staff assessment and affect its motivation using effective encouragement tools a manager should create the proper conditions of the enterprise functioning by all the criteria: industrial and technological, organizational and corporate, financial and economic, social and labour, economic and environmental (Figure).

The efficiency to achieve good results while assessing staff activity is determined by two important components: external (the incentives that shape the efficiency of the enterprise) and internal (motives that shape an employee's needs satisfaction), which form two levels of influence: external and internal. Thus, the achievement of the high staff performance is influenced by the proposed tools: of the external influence: "The system of staff labour activity activation" by stimulating the criteria of industrial and technological, financial and economic, social and labour, organizational and corporate, economic and environmental nature of the enhancement of the staff productivity and internal influence: "Assessment of performance of managers, experts, specialists, officials, blue collars in the system of improving the work quality and effectiveness" by the quantity as- sessment of the works performed and "Assessment of performance of direct, auxiliary workers and operators in the system of improving the work quality and effectiveness" by the assessment of quality and timely performed works. The tools to enhance the motivation of efficient staff labour is the system of staff labour activity activation and assessment of performance of direct, auxiliary workers and operators to improve the quality and efficiency of work.

According to the practice of international organizations' activities, the properly chosen methods of comprehensive staff activity assessment helps form an employee's motivation expectations related to the permanent process of intellectual and emotional improvement of his/her personality.

Thus, in order to improve the efficiency of modern methods of staff activity assessments we deem it advisable to take into account the following factors:

- provision of feedback to participants of assessment process (providing information to employees about the assessment purpose, procedures and criteria);

- ensuring the staff assessment efficiency;

- promotion of assessment procedures flexibility (due to flexibility a specialist can take the position of different points of view and objectively consider different situations);

- ensuring the assessment predictability (for further planning of management decisions).

Conclusions and recommendations for further research. Thus, the performed analysis gives reason to affirm that the selection of the methodological approaches to the staff performance assessment is not perfect and not researched thoroughly, which has determined our more in-depth study of the issue, the tasks of which involved the search and detailed analysis of the most common methods and techniques of staff performance assessment; study and classification of the staff activity assessment types; formation of the system of indicators

\begin{tabular}{|c|c|c|c|c|c|c|}
\hline \multirow{6}{*}{ 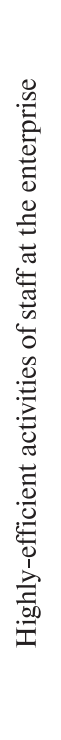 } & \multirow{2}{*}{ 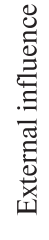 } & \multicolumn{5}{|c|}{ The system of staff labour activity activation at the enterprise } \\
\hline & & $\begin{array}{c}\text { Industrial } \\
\text { and technological } \\
\text { criterion }\end{array}$ & $\begin{array}{l}\text { Organizational } \\
\text { and corporate } \\
\text { criterion }\end{array}$ & $\begin{array}{c}\text { Financial } \\
\text { and economic } \\
\text { criterion }\end{array}$ & $\begin{array}{c}\text { Social } \\
\text { and labour } \\
\text { criterion }\end{array}$ & $\begin{array}{c}\text { Economic } \\
\text { and environmental } \\
\text { criterion }\end{array}$ \\
\hline & \multirow{4}{*}{ 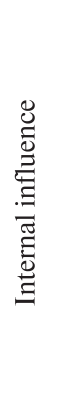 } & \multicolumn{5}{|c|}{$\begin{array}{l}\text { Assessment of performance of managers, experts, specialists, officials, blue collars } \\
\text { in the system of improving the work quality and effectiveness }\end{array}$} \\
\hline & & \multicolumn{2}{|c|}{ Quality assessment of the work performed } & \multicolumn{3}{|c|}{ Quantity assessment of the work performed } \\
\hline & & \multicolumn{5}{|c|}{$\begin{array}{l}\text { Assessment of performance of direct, auxiliary workers and operators in the system } \\
\text { of improving the work quality and effectiveness }\end{array}$} \\
\hline & & \multicolumn{2}{|c|}{ Quality assessment of the work performed } & \multicolumn{3}{|c|}{ Assessment of the timely performed work } \\
\hline
\end{tabular}

Fig. The influence of motivation and encouragement systems on the achievement of good results at staff performance assessment 
of its performance comprehensive assessment; search of correlation of the staff performance assessment technique with the influence of staff motivation and encouragement systems. The author's further studies involve identifying the factors and criteria for the staff motivation and encouragement assessment as well as the benchmarking application in the staff performance assessment, which is used as a benchmark assessment of employees and can be used at different levels and cover a total HR management processes at an industrial enterprise and form appropriate measures to convert them into results.

\section{References.}

1. Gavrilova, O. G., 2009. Staff Assessment and its Dissimilarity from the Certification. Financial newspaper Expo [online], 2. Available at: <http://www.gradientalpha.ru/ocenka-personala-i-eyo-otlichie-ot-attes/> [Accessed 14 May 2017].

2. Kolot, A. M., Hrishnova, O. A., Herasymenko, O. O. and Zavinovska, H. T., 2009. Labour Economics and Labour Relations. Kyiv: Kyiv. nats. ekon. un-t im. V. Hetmana [pdf]. Available at: <http://nikiforova.vk.vntu. edu.ua/file/20f1e1d7879d18b0878fd640956702de.pdf> [Accessed 23 March 2017].

3. Kolot, A. M., 2014. Motivation and motivation process at the industrial enterprise: modern understanding, main provisions. Bulletin of the National Technical University "KhPI". Series: Technical progress and production efficiency [online], 1, pp. 82-92. http://nbuv.gov.ua/UJRN/ vcpitp_2014_64_9> [Accessed 11 March 2017].

4. Tsimbalyuk, S. A., 2009. Grading system of assessing job positions and remuneration of labour: methodology, methods, and practices. Spravochnik kadrovika [online], 2. Available at: <http://www.politik.org.ua/vid/ magcontent.php3 $\mathrm{m}=8 \& \mathrm{n}=23 \& \mathrm{c}=268>$ [Accessed 17 March 2017].

5. Ivanova, M.I. and Yehorova, N.O., 2011. Using modern methods of staff management at industrial enterprises. Ekonomichnyi Visnyk Natsionalnoho Hirnychoho Universytetu, 3. Available at: <http://ev.nmu.org.ua/ docs/2011/3/EV20113_082-091.pdf> [Accessed 21 April 2017].

6. Mukha, R., 2015. Labour Productivity at the Enterprises and the Basic Directions of its Increase. Halytskyi Ekonomichnyi Visnyk, TNTU, 48(1), pp. 82-92.

7. Savchenko-Svatko, O., 2009. Diagnostic tools of personnel auditing of local self-governing authorities. Publichne administruvannia: teoriia ta praktyka [pdf], 2(2). Available at: <http://www.dridu.dp.ua/zbirnik/200902/ 09somoms.pdf $>$ [Accessed 5 April 2017].

\section{Оцінювання праці в системі мотивації персоналу підприємств}

\section{А. О. Климчук}

Вінницький національний аграрний університет, м. Вінниця, Україна, e-mail: alena_klumchyk@ukr.net

Мета. Розробка конкретних методичних підходів щодо оцінювання діяльності працівників про- мислових підприємств у формуванні мотивації та стимулювання їх праці.

Методика. Дослідження здійснюється на основі застосування фундаментальних і сучасних положень економічної теорії, менеджменту, даних наукових шкіл теорій мотивації зарубіжних і вітчизняних учених-економістів, фахівців у галузі управління персоналом. За допомогою системного аналізу й синтезу досліджено сутність оцінювання діяльності персоналу й визначено його значення у процесі управління. Метод порівняння використано для вивчення методичних підходів до оцінювання діяльності персоналу на зарубіжних і вітчизняних підприємствах та організаціях, графічний метод для схематичного зображення впливу систем мотивації на оцінку діяльності персоналу. Класифіковані види оцінювання персоналу з їх розмежуванням для керівників різних рівнів, фахівців, спеціалістів, технічних службовців і робітників, що дозволить визначати критерії оцінки роботи персоналу в залежності від поставлених завдань підвищення мотивації його трудової діяльності. У роботі використано метод побудови показника, що містить у собі кількісне оцінювання діяльності персоналу підприємства на основі балів.

Результати. Доведено важливість і значення методичного підходу до оцінювання діяльності персоналу різних професійно-кваліфікаційних груп, проаналізовані традиційні та інноваційні методи оцінювання на підприємствах. 3 метою вирішення існуючих проблем щодо вибору адекватних методик оцінки роботи персоналу на вітчизняних підприємствах, нами була розроблена рекомендаційна класифікація видів оцінювання роботи персоналу з вибором конкретних видів для працівників різного рівня кваліфікації та запропоновано використовувати комплексне оцінювання на основі кількісного вираження за допомогою балів. Зроблено висновок, що ефективність досягнення високих результатів в оцінюванні діяльності персоналу визначається двома важливими компонентами: зовнішніми (стимули, що формують результативність діяльності підприємства) та внутрішніми (мотиви, котрі формують задоволення потреб працівника).

Наукова новизна. Розроблення методичного підходу щодо оцінювання діяльності персоналу, що складає ядро мотивації праці персоналу й забезпечує зацікавлене досягнення поставлених цілей, дозволяє виявити слабкі місця в діяльності підприємства та зацікавити самих працівників у виправленні ситуації, що склалася. У результаті проведення правильного оцінювання діяльності персоналу можливим є отримання інформації щодо ефективності роботи працівників, потенційних можливостей спеціалістів і перспектив їх кар'єрного зростання, причин неефективної роботи окремих працівників, потреб і пріоритетів у навчанні та підвищенні кваліфікації, вибору ефективних інструментів у стимулюванні трудової діяльності.

Практична значимість. Застосування комплексної методики оцінювання діяльності персоналу 
дає змогу ефективно здійснювати оцінювання як окремого працівника різної професійно-функціональної категорії персоналу, так і грипи персоналу, що дозволяє в подальшому запропонувати систему заходів його мотивації та стимулювання. Запропоновані види оцінювання дозволять обирати види й методи оцінювання для керівників різних рівнів, фахівців, спеціалістів і робітників структурних підрозділів, визначати критерії оцінювання персоналу в залежності від поставлених завдань підвищення його мотивації та стимулювання.

Ключові слова: оцінювання діяльності персоналу, комплексна методика оцінювання

\section{Оценка труда в системе мотивации персонала предприятий}

\section{А.О. Климчук}

Винницкий национальный аграрный университет, г. Винница, Украина, e-mail: alena_klumchyk@ukr.net

Цель. Разработка конкретных методологических подходов к оценке деятельности работников промышленных предприятий в формировании мотивации и стимулирования их труда.

Методика. Исследование осуществляется на основе применения фундаментальных и современных положений экономической теории, менеджмента, данных научных школ теорий мотивации зарубежных и отечественных ученых-экономистов, специалистов в области управления персоналом. С помощью системного анализа и синтеза исследована сущность оценки деятельности персонала и определено его значение в процессе управления. Метод сравнения использован для изучения методологических подходов к оценке деятельности персонала на зарубежных и отечественных предприятиях и организациях, графический метод - для схематического изображения влияния систем мотивации на оценку деятельности персонала. Классифицированы виды оценки персонала с их разграничением для руководителей различных уровней, специалистов, технических служащих и рабочих, что позволит определять критерии оценки работы персонала в зависимости от поставленных задач повышения мотивации его труда. В работе использован метод построения показателя, который содержит в себе количественное оценивание деятельности персонала предприятия на основе баллов.

Результаты. Доказана важность и значение методологического подхода к оценке деятельности персонала различных профессионально-квалифи- кационных групп, проанализированы традиционные и инновационные методы оценки на предприятиях. С целью решения существующих проблем по выбору адекватных методик оценки работы персонала на отечественных предприятиях, нами была разработана классификация видов оценки работы персонала с выбором конкретных видов для работников разного уровня квалификации и предложено использовать комплексную оценку на основе количественного выражения с помощью баллов. Сделан вывод, что эффективность достижения высоких результатов в оценке деятельности персонала определяется двумя важными компонентами: внешними (стимулы, формирующие результативность деятельности предприятия) и внутренними (мотивы, которые формируют удовлетворение потребностей работника).

Научная новизна. Разработка методологического подхода к оценке деятельности персонала, что составляет ядро мотивации труда персонала и обеспечивает заинтересованность в достижении поставленных целей, позволяет определить слабые места в деятельности предприятия и заинтересовать самих работников в исправлении сложившейся ситуации. В результате проведения правильной оценки деятельности персонала возможно получение информации об эффективности работы сотрудников, потенциальных возможностях специалистов и перспектив их карьерного роста, причинах неэффективной работы отдельных работников, потребностях и приоритетах в обучении и повышении квалификации, выборе эффективных инструментов в стимулировании трудовой деятельности.

Практическая значимость. Применение комплексной методики оценки деятельности персонала позволяет эффективно осуществлять оценку как отдельного работника различной профессионально-функциональной категории персонала, так и группы персонала, что позволяет в дальнейшем предложить систему мер мотивации и стимулирования деятельности. Предложенные виды оценки позволят выбирать виды и методы оценки для руководителей различных уровней, специалистов и рабочих структурных подразделений, определять критерии оценки персонала в зависимости от поставленных задач повышения его мотивации и стимулирования.

Ключевые слова: оценка деятельности персонала, комплексная методика оценки

Рекомендовано до публікації докт. екон. наук В.М.Нижником. Дата надходження рукопису 20.04.17. 